than not promotes rather than resists constructive change.

For too long the rule of the game has been to spend more or lose physician support. We've spent more - a lot more - and the return on investment has been low. Canada is a country governed by elites. Will the medical profession rise to the challenge of creating a new and improved medicare, or will it, like so many elites, talk about the public interest but act in the interests of the few?

Steven Lewis is with Access Consulting Ltd., in Saskatoon, Sask., and the Centre for Health and Policy Studies, University of Calgary, Calgary, Alta.

Competing interests: None declared.

\section{References}

1. Chaoulliv. Quebec (Attorney General). 2005 SCC 35.

2. Sullivan P. Private health care dominates meeting as General Council calls for national debate. CMA7 1995;153(6):801-3.

3. Sullivan P. Focus groups confirm that MDs, public differ on role of private health care. $C M A 71996 ; 154(8): 1247-9$.

4. Kennedy J, Quan H, Ghali WA, Feasby TE. Variations in rates of appropriate and inappropriate carotid endarterectomy for stroke prevention in 4 Canadian provinces. CMA7 2004;171(5):455-9.

5. Jaglal SB, Carroll J, Hawker G, McIsaac WJ, Jaakkimainen L, Cadarette SM, et al. How are family physicians managing osteoporosis? Qualitative study of their experiences and educational needs. Can Fam Physician 2003;49:462-8.

6. Brownell M. Tonsillectomy rates for Manitoba children: temporal and spatial variations. Healthc Manage Forum 2002;Suppl:21-6.

7. Katz A, DeCoster C, Bogdanovic B, Soodeen RA, Chateau D. Using administrative data to develop indicators of quality in family practice. Winnipeg: Manitoba Centre for Health Policy; 2004. Available: www.umanitoba.ca/centres /mchp/reports/pdfs/quality_wo.pdf (accessed 2005 Jun 20).
8. Medical Reform Group. Nearsighted physicians reject deal with government [media release]. Toronto: The Group; 2004 Nov 21. Available: www.hwcn.org /link/mrg/press.release.html\#Nearsighted_Physicians_Reject_Deal_With (accessed 2005 Jun 20).

9. Sanmartin C, Shortt SED, Barer ML, Sheps S, Lewis S, McDonald PW. Waiting for medical services in Canada: lots of heat, but little light. CMA7 2000;162(9):1305-10.

10. Department of Health. Achieving shorter waits: the PPF promises shorter waiting times across the service. London (UK): The Department; 2005. Available: www.dh.gov.uk/PolicyAndGuidance/PatientChoice/WaitingBooking Choice/WaitingBookingChoiceArticle/fs/en?CONTENT_ID=4066038\&chk =ZurIX5 (accessed 2005 Jun 20).

11. Winnipeg Regional Health Authority. Health services wait time information: cardiac surgery. Winnipeg: Manitoba Health. Available: www.gov.mb.ca/health /waitlist/cardiac.html (accessed 2005 Jun 20).

12. Median wait times and wait lists. Victoria: Government of British Columbia 2005 Mar 31. Available: www.healthservices.gov.bc.ca/cpa/mediasite/waittime /median.html (revised 2005 May 17, accessed 2005 Jun 20).

13. Wait time information. Regina: Saskatchewan Surgical Care Network. Available: www.sasksurgery.ca/wait-list-info.html (accessed 2005 Jun 20).

14. Copeman D. Interview with Don Copeman, Copeman Health Centre, Vancouver. Interviewed by Barbara Budd and Mary Lou Finlay, As It Happens [radio program]; 2005 Jun 1. Produced by the Canadian Broadcasting Corporation, Toronto. Available: www.cbc.ca/insite/AS_IT_HAPPENS_TORONTO /2005/6/1.html (accessed 2005 Jun 20).

15. Duckett SJ. Private care and public waiting. Aust Health Rev 2005;29:87-93.

16. Tu JV, Pinfold SP, McColgan P, Laupacis A. April 2005. Access to bealth services in Ontario: ICES Atlas. Toronto: Institute for Clinical Evaluative Sciences; 2005. Available: www.ices.on.ca/webpage.cfm?site_id=1\&org_id=67 \&morg_id=0\&gsec $i d=0 \&$ item id=2862\&type=atlas (accessed 2005 Jun 20).

17. McGregor MJ, Cohen M, McGrail K, Broemeling AM, Adler RN, Schulze $\mathrm{M}$, et al. Staffing levels in not-for-profit and for-profit long-term care facilities: Does type of ownership matter? CMA7 2005;172(5):645-9.

Correspondence to: Steven Lewis, Access Consulting Ltd., 211-4th Ave. S, Saskatoon SK S7K 1N1; fax 306 343-1071; steven.lewis@shaw.ca

Viewpoint

\title{
Doctors put patients first in health care debate
}

\section{Albert Schumacher}

Published at www.cmaj.ca on July 14, 2005. A French translation is available at www.cmaj.ca/cgi/content/full/173/3/277/DC1.

B See related articles pages 269, 271, 273 and 275

I $\mathrm{t}$ is truly unfortunate that Steven Lewis' misguided and misleading commentary ${ }^{1}$ comes at such a critical point in the history of medicare in this country. While I welcome his call to the medical profession to "rise to the chalके lenge of creating a new and improved medicare," it is unacceptable to ignore and denigrate the profession's longstanding commitment to ensuring Canadians' access to health care services throughout our nation's history. Lewis' comments truly detract from the serious policy questions that we now face.

The CMA's support for a publicly funded health care system is a matter of historical record. In 1934, the CMA produced guidelines for a national health program funded and administered by the state. ${ }^{2}$ When medicare was being introduced, the CMA fought to ensure that the doctorpatient relationship and clinical autonomy were preserved under the new system, principles that we continue to champion today. Unfortunately, Lewis confuses the support for these principles with opposition to an efficient and equitable public health care system. Then, as now, doctors will continue to embrace change that is clearly targeted to better patient care, while being rightfully skeptical of 
government-initiated reforms focused on cost control without considering patient needs.

The CMA continually generates new ideas, debate and recommendations to make the system work better for our patients. Whether it was protesting the decision of all governments to reduce the number of medical students trained in the early 1990s, or warning that the "Canada Health and Social Transfer" introduced in 1995 amounted to an abrogation of the federal government's responsibility to maintain the Canada Health Act, the CMA has a track record for seeking out real action and proposing real solutions.

More recently, this work has continued through the $A$ Prescription for Sustainability ${ }^{3}$ document submitted to Roy Romanow's Commission on the Future of Health Care in Canada and into The Taming of the Queue: Toward a Cure for Health Care Wait Times, ${ }^{4}$ released jointly with the Canadian Nurses Association, and discussed at last fall's First Ministers' Meeting on Health Care.

As interveners in the Chaoulli v. Quebec case ${ }^{5}$ before the Supreme Court of Canada, the CMA reaffirmed its support for a publicly funded health care system where access is based upon need and not the ability to pay. This support is based on the belief that such a system provides the best health outcomes for our patients and all Canadians. However, a health care system that fails the basic test of providing timely access to care is not viable, and therefore not sustainable. If governments don't act to provide adequate resources under the public system, then the social contract that is medicare is in jeopardy.

Medicare is in fact a complex and delicate arrangement that involves 13 separate health insurance plans chugging away under a general set of directions called the Canada Health Act. The Act is a true, time-tested encapsulation of the principles underlying how health care services should be paid for in this country.

To remain viable in today's environment, the Act needs leadership from governments and practical solutions from health care providers, policy experts and administrators and most of all from patients and the public. At a practical level, it needs to open up the inward-looking policy process to gather ideas from myriad sources and put them into action. An example of this is the Wait Time Alliance, which has reached consensus on benchmarks for timelines for access to care and will soon be presenting a "tool box of strate- gies" to help all governments ensure Canadians receive timely access to medical services.

Contrary to what Lewis asserts, the reason the Canada Health Act is in trouble today has nothing to do with a lack of support from the medical profession. Evidence overwhelmingly points to limited capacity and health human resources as the fundamental problems. Assertions that doctors are leaving people to wait longer for personal gain are untrue and offensive to Canada's doctors, who day in and day out put their patients' needs first, often at great personal sacrifice. Our goals are and have always been timely access, professional autonomy and quality patient care.

When the Supreme Court released its decision on June 9, I made the following statement on behalf of the CMA membership: "One thing that is certain is that we physicians will continue to put our patients first. I took an oath to do my best for my patients - as did all my fellow doctors - and that will not change just because our national health insurance program now faces important changes."

The CMA will be discussing in the weeks and months ahead how to strengthen the publicly funded health care system in Canada in light of the reality of the Supreme Court's decision. We are now in a very nuanced debate, one that requires considered thought and focus on facts. I know that the focus of Canada's physicians will remain where it always has: on doing the best for our patients.

Dr. Schumacher is President of the Canadian Medical Association.

Competing interests: None declared.

\section{References}

1. Lewis S. Physicians, it's in your court now. CMA7 2005;173(3):275-7.

2. Canadian Medical Hall of Fame. Description of laureates. London $(\mathrm{ON})$ : Hall Associates; 2004. Available: http://cdnmedhall.org/laureates/?laur_id=68 (accessed 2005 Jul 6)

3. Canadian Medical Association. CMA submission to the Romanow report: a prescription for sustainability. Ottawa: The Association; 2002.

4. Gruenwoldt E, Saulnier M, Shortt SED. The taming of the queue: toward a cure for bealth care wait times. Ottawa: Canadian Medical Association/Canadian Nurses Association; 2004.

5. Chaoulliv. Quebec (Attorney General). 2005 SCC 35.

Correspondence to: Dr. Albert Schumacher, Canadian Medical Association, 1867 Alta Vista Drive, Ottawa ON K1G 3 Y6 